\title{
Cohabitation Government Policies-Toward a New Description of the Political Regime
}

\author{
Farah Dhiaa Hussein Mubarak Al-Safaar \\ University of Baghdad, Baghdad, Iraq
}

\begin{abstract}
The cohabitation idea includes the harmony between the government and political systems, to built this idea, it needs political tools, administration, and public policy, then, the cohabitant policies that fulfill needs and achieve more societal satisfaction. Cohabitation creates deliberate democracy emerged from social interactions such as seeking changes, achieving political and social cohabitation, they are filling gaps between ruler and ruled. Transition from simple understanding to revealing complex societal challenges and admitting it, promoting measures for conversation and general speech, transforming focus from competitive interests to general interest, promoting the public capability of making insightful rational decision, planting values in deliberation and decision-making, increasing awareness of citizen activity, enhancing relations between citizens and issues, institutions and political system, entrusting responsibility to the public about general policies, offering transformational learning chances and organized systematic change. Cohabitation policies rely on demands, decisions, contents, outputs, and reflective effect determined by the size of societal satisfaction. The active construction of institutional political action machineries, cohabitation policies are constructed on societal resultants and can be transformed into cohabitation tools and policies which will be reflected to society as there is a quote says "Policies mostly amended rarely altered".
\end{abstract}

Keywords: cohabitation, harmonic, government

"As much as we can imagine: The essential aim of the human existence is making light in the darkness of the wide life" (C. J. Joung ${ }^{1}$ ).

The race of knowledge can encompass more than one competitor and more researchers to seek this knowledge.

The idea of general policies that include tools and machineries to encourage researchers as considered the nearest means to societal interaction is cohabitant policies that fulfill needs and achieve more societal satisfaction.

The interest in general policies internationally started in the mid-19th century as traditional interest in general policies was taught as legislative, executive, judicial authorities' separation of powers, relations among institutions were a part from general policies, therefore, it was called (narrow range) phase.

In the 20th century, it started another phase called (political everywhere) according to a joined machinery

Corresponding author: Farah Dhiaa Hussein Mubarak Al-Safaar, Ph.D., assistant professor, Department of Political Systems, College of Political Science, University of Baghdad; research fields: political science, public policy, governance, political government, and political systems. E-mail: dr.farahmubarak@yahoo.com.

${ }^{1}$ Sursar Mohmaed. (2007). The laws-Tunis-The first school-Higher education (p. 23). 
as finding the unpolitical in political matters. In the middle of 20th century:

(1) Teaching the behavioral accompanying the work of government and its analysis;

(2) Studying social and psychological rules of individual and group behavior as well as studying struggling behavior between executive and legislative authorities which lead to study the processes, reasons, activities, and results concentrating on behavioral and descriptive side of general policies.

After the Second World War, it concentrated on the concept of general policies, mediated its objectives within an analytical frame according to available priorities and capabilities, with a developing call to increase state interference, thus, this phase is called "analytical policies".

The 50s of the 20th century refreshed general political science in an experimental intellectual feature belonging to Harold Lasoel's efforts which made politics as the base for distributional and structural processes of benefits and values that make and implement general policy.

In the 21st century, it started the phase (general range) to include inputs and outputs, interactions and activities, governmental organs organizations, and decisions and activates. In the mid-21st century, it was substituted with the role of state along with raising interaction levels and the increasing role of general and special sectors [non-governmental organizations (NGOs)], revealing its fast capabilities to interfere with the states internal general policy, amend, direct, and concentrate on the new players' role in general policy.

Therefore, the role of general policy is to work on mingling political variables with social needs and nature of governments with its role in making social general policies in cohabitant forms.

Cohabitation is a means and machinery of coexistence, institutional, and political twinning. The researcher derives the cohabitation idea from the first cohabitant government in France, the right and radicalism coexisting for two years only. It was the first time in the history of that witnessed hardship of harmony between opposites.

The idea may achieve "cohabitation" between powers inside political systems that depended on a variation of procedures, systems, and orders which complicate the harmony except in a constitutional legal frame.

\section{The Study of the General Framework}

\section{The Significance of the Study}

The recognition of general policies and nature of political system, its approaches and the method of achieving governmental cohabitation within general policies encourage the idea of cohabitation government policies.

\section{The Problem of the Study}

The general policies depend on means, machineries, and methods to make decisions, framing orders and procedures on which it depends. Political system depend on different manners, and it is controlled by interests and external and internal pressures. Then, the problem is how to mix the rigidity with the flexibility.

\section{Hypothesis of the Study}

The sketching and preparation of general policies imposed on political system, a kind of commitment within a constitutional shield which is reflected on the forms of political system.

\section{Approach of the Study}

The analytical descriptive approach is employed to suit the nature of this study to determine political system and its policies. 


\section{Chapter One: Concepts Between Government and Cohabitation}

"Politics is the art of governing human communities” (Robear Mujaam²).

\section{The Religious Origin of Cohabitation}

Cohabitation in Islam is forgiveness, coexistence, renouncing differences of comfort, tolerance, coexistence, and cohabitation ${ }^{3}$.

\section{The Origin of the Term Cohabitation}

Cohabitation is derived from "cohabitant", a new derivation not frequent in the language, its root is "cohabit”, cohabit in one house, i.e., a couple live together. Cohabitation in Sihah Aljawhari Encyclopedia is home ${ }^{4}$.

\section{Political Origin of Cohabitation}

The origin of the term "cohabitation" is from "cohabit" as a political term since the year 1986. It was used for the first time when Franswa Metearan was obliged to appoint Jack Sherack as a prime minister (1986-1988) in spite of both being from opposite parties, the first is socialist and the latter is rightist. Practically, "cohabitation” is represented in Metearan Cohabiting Ladward Baladour (1993-1995), and Sherack cohabiting with the socialist Lionel Jospin.

Cohabitation in politics is in the sem-presidential system, and it lives for short span of time.

In later years, specifically in the beginning of the last half of the 90s, Lebanese used the term cohabitation (live together with, had a Latin origin) to express this meaning in English and French languages. It is a Quranic expression which the Lebanese, Christians, and secularists were more adequate in using this Islamic term than others.

The linkage of this term with political organization of political system was in the thought of Talcot Barsins when he said that political and social organization structure needed mutual response and trust between ruler and ruled. Obviously, he was suggesting to a cohabitation process between political system and people to confront any problem without violence. Carl Deutch looked to political system as a complementary connection process among political units as he suggested two patterns to achieve societal security:

(1) United security pattern: It is common harmony and benefit;

(2) Multi-security pattern: It is coordinating values among decision maker, citizen, and the common response by peaceful means ${ }^{5}$.

Both patterns referred to mutual utility, response, and coordination of values, and economical, social, political benefits which reflected a real desire of societal cohabitation. There is another opinion as Dr. Muhammed Hamid looked to cohabitation as "The connection between ruler and citizen in the Arab world is a cohabitant connection. Not a citizenship connection”. He referred to it as neighbouring relation and not a marital connection as he expressed his idea by saying:

Really we use citizenship word but know nothing about its meaning, because citizenship means participating in the nation's responsibility in rights and duties, we are in the Arab homeland in the tyrannical districts in a state called cohabitation, the ruler allows us to live and work beside him, but he can seize every right at any moment, thus this is not

\footnotetext{
${ }^{2}$ Dr. Saub Hassan. (1977). The political science (p. 21). Beirut: Almacen Publisher.

${ }^{3}$ Deab, W. (2013). Islam is forgiveness (p. 12). Bahrain College.

4 The Middle East Newspaper. (2012). The Arab freedom. No. 12162.

${ }^{5}$ Researches Tegareed. The political system. Retrieved from http://vb.tgareed.com.
} 
citizenship, and we cannot call this cohabitation-possibility of living in this country or that—citizenship, because the ruler can imprison you, grab your money, and punish you at any moment, this is cohabitation not citizenship. Citizenship means that you have rights, abide by duties, and the same to the ruler. This is done by replacement and participation which is absent in the Arab community and all are included.

Dr. Mohamed deprived the relationship of rulers and ruled of any way of coexistence, response, and cohabitation.

It seemed that his opinion was far from the world of democracy to the extent that cohabitation is fixed in the nature of the relationship between ruler and ruled.

Citizenship is the active and aware participation of each person without exception or recommendation of any kind. It starts with building the cultural, political, and social frame of the state. This principle is applied on any society according to essential considerations, they are ${ }^{6}$ :

(1) The suitability of the state nature and pattern with the nature of citizenship;

(2) The active response with idea of citizenship in the social and political aspects;

(3) Employing democracy and its limits;

(4) Availability of intellectual conviction and spiritual acceptance of the principle;

(5) Political commitment of citizenship principle represented in societal consent;

(6) Constitutional items that protect citizenship principle based on social contract (constitution) to include citizenship principle as source of rights and duties to everyone have the nationality of the state without religious, sectarian, and racial discrimination.

Thinkers see that citizenship is the fruit of the ruled struggle to deprive stranger rulers - the authority according to Robert Dahl's description of the current democratic practice and practice of citizenship principle.

To him, the citizenship principle is determined in the acceptance of free active participation right for all individuals equal in rights and duties. It extends to include the right of participation in the economical activity, enjoying wealth, and participation in the social life as well as making obligatory group decisions, holding general offices and being equal in front of law ${ }^{7}$.

Cohabitation creates deliberate democracy defined by Philip Thomas in the list of 10 positive gains emerged from social interactions such as seeking changes, achieving political and social cohabitation, they are ${ }^{8}$ :

(1) Filling gaps between ruler and ruled;

(2) Transition from simple understanding to revealing complex societal challenges and admitting it;

(3) Promoting measures for conversation and general speech;

(4) Transforming focus from competitive interests to general interest;

(5) Promoting the public capability of making insightful rational decision;

(6) Planting values in deliberation and decision-making;

(7) Increasing awareness of citizen activity;

(8) Enhancing relations between citizens and issues, institutions and political system;

(9) Entrusting responsibility to the public about general policies;

(10) Offering transformational learning chances and organized systematic change.

This will position citizen in it, the state combine elements such as population, territory, natural resources,

${ }^{6}$ The Middle East Newspaper. (2012). The Arab freedom. No. 12162.

7 Barakat, Yasser. The citizenship principles. Retrieved from http://www.mcsr.net/activities/007.ht.

8 Tomas Fillip. (2011). UNDP Programs-The democracy (p. 50). 
government military, and civil institutions as well as basic structures that will shape the state and political system. So the government is tackled as a basic political element affecting the directing of the state in general. With a system of running the state and the means of authority on people, dealing with its matters, directing its efforts, organizing itself, controlling behavior of individual and groups by laws put down by the authority reinforcing them. The power of the government is a capability which enables it to control, regulate, press, and observe people to gain obedience. The character of authority springs from tradition, or as a result of wealth or military force monopoly as it is a relation among the master, controlled, competition, and cooperation ${ }^{9}$.

The government as an institution includes all the opposites inside the nation and reflects population's desires in its political forms as it is the melting pot of political action that procure political decisions after huge political, social, and economical interactions inside government organ which consists of active characters in the political action chosen by democratic means or by autocratic manner (absolute authority) or by hereditary despotism and other manners in choosing rulers such as: self-renewal, seizure of authority, heredity, self-selection.

\section{Governing Systems}

There are four types of government system, they are as follows ${ }^{10}$ :

First: single authority system. The government institution consists of active control of one person of political, economical, social matters, public matters suiting the visions. It is a dangerous system because it depends on the ruler character and ceases to exist in his/her disappearance.

Second: bilateral government system. The power is to two equal persons in authority and rank. They have joint decisions and work in one direction, the decision cannot be issued if one opposes it.

Third: collective authority system. A system that enumerate the government to a small group that has equality and humbleness as their characteristics in making decisions, all group shares in making any political decision.

Fourth: dual authority system. It combines the collective authority and presidential system. The president has a ministerial organ which its members are appointed by him. They are a link between president and parliament.

This collective organ enjoys independence and can cooperate with parliament to restrict the president authority. It is empowered to take decisions and it has a head who is the first minister or prime minister, whose authority is parallel to the president.

The researcher here describes the functional government's characteristics:

(1) Political: functions according to the state's higher political interest;

(2) Rational: Functions within rational norms, hence, it has reasonable decisions;

(3) Factual: Functions within social, political, and economical reality, hence, its decisions have actual forms;

(4) Definite restricting: makes definite restricting decisions governed by law to control the course within a legal frame.

The legitimacy of government relies on the political authority that contributes to political thought on which the ruler ruled to achieve political settlement. Consequently, it will lead to make fiber idea of super

\footnotetext{
${ }_{9}^{9}$ Badwee, Ahmad. (2004). The political ideas (2nd ed., pp. 64-115). Cairo: Amasree Publishing.

10 Dovergeh, Morise. Political systems (pp. 15-16). Cairo: Kameel Publishing.
} 
power that can make miracles. This does not mean that it is the legal authority which is joint with group right similar to "government right" as G. Bodan called it.

Here the government works to reach its objective by continuance and absolute sovereignty through political system which is a harmony and balance philosophy among opposite, dissidents, fighting of ideas and directions. The group of institutions among which the machinery of political action is distributed is the political system distinguished by affording a supreme responsibility. A political system is a group of necessary solutions to confront problems raised by governing organs that are organized in a special organ. Accordingly, the political system can be understood as ${ }^{11}$ :

(1) Political system is a means of political interaction;

(2) Political system is the authoritative distribution of values;

(3) Political system is the authoritative allocation of values;

(4) Political system is a constant pattern of human relations;

(5) Political system is a form of social organ;

(6) Political system is described according to a legal form;

(7) Political system is made as inputs and outputs.

\section{Chapter Two: Constitution and Cohabitation}

The state has the only qualified ability to control competition among authorities in a society, seeking understanding, not alienation, but practically the opposite is true. Goorge Bordon said: "It is certain that any society cannot continue in this race if the confronting power is determined not to accept any compromise"12.

Constitution is the means of legal compromise, and it is the structure of rules that affect directly and indirectly on sovereignty and authority practice in the state. So, constitution is a bunch of principles that control the relation between government authorities and the ruled rights.

The cohabitation contract is customary one unwritten in any form in constitutions of the world especially that constitutions reflect the political system of the state through which the governing system can be known, as well as the relation between ruler and ruled, and the bunch of rules organizing public and political affairs.

Dr. Disea defines it as a group of rules, organize directly or indirectly the distribution and the practice of the state supreme power. Adrelou sees that the constitution is the law of political authority or a group of rules that defines the authority and organizes its transference. Maurice Dovergeau defines constitution as a branch of public law which defines the forming of political organs and organizes its activity in the state. The expert Dr. Eurventous said that constitution is the making of liberty, it is only a tool of conformity between authority and liberty. It is a consensual technique between authority and liberty at the same time.

The most important manner of writing constitutions is the undemocratic manner which is granting and the manner contract. The democratic manner is by institutional assembly or by public referendum.

The nature of legal constitutions is represented in restricting rules with a political nature concerned about rules and procedures that have the right of obedience specially that political course constitutions on achieving the purposes ${ }^{13}$ :

(1) Achieving human admission of human;

\footnotetext{
11 Bordoo, G. (2002). State (3rd ed., pp. 43-53). Translated by S. Hadad. Almmen Publishing.

12 Abdoria. (1988). The theories of the state (p. 99). Translated by Nory Mohamed.

13 Al-Mashehadany, Mohamaed. (1991). The political system (pp. 53-54). The College of Law, University of Mosul.
} 
(2) Founding limits for individual and society interest;

(3) Evaluating limits between ruler and ruled.

The constitutional rules based on legal frames encompass political relations in the frame of society particularly that world constitutions resort to constitutional to frame political activities and legal rules by ${ }^{14}$ :

(1) Trusting the individual as a basis to achieve liberty;

(2) Fixing political and civil rights;

(3) Depending on constitution as a means of understanding and cohabitation;

(4) Believing in multilateral opinions and freedom of opposing opinion;

(5) Depending on organization;

(6) Creating organizing limits and basics.

Constructing rational political cohabitation machineries without existence of written rules needs "ordered dynamic process that has mutual moving traits and interactive, compromising methods”, according to Bejamin Crousbi. It also needs machineries which $\operatorname{are}^{15}$ :

(1) Social balance;

(2) Political balance—-through political replacement and alternation;

(3) Balance among institutions, i.e., between authority and local authorities, and among authority, parliament, and government.

In spite of the existence of constitutional machineries, the undertaking of functional dual system is the field of political action represented in powers of common authorities, i.e., suggesting and issuing laws. It is a legislative specialization unless the dual system is employed, the executive authority has the right to participate in this institutional action, and committing legally if both authorities endorse it after discussion and agreement, then, it transforms to a valid legislation.

Any suggestion from one of these authorities refused by the other will neglected as long as the machinery of dual work is reasonable politically and institutionally. There are factors besides constitutional rules that affect the political process. Election and party systems are considered as cohabitation machineries in all political system (how far is democratic system considered immune against all internal challenges that political system and security may confront?). The appearance of electoral system is more flexible and responsive to variables in public opinion and political demands.

It is necessary to reveal some electoral system, they $\operatorname{are}^{16}$ : strategic policy-transforming single vote system, best losers system, accumulation system, single winner system, party bloc system, and alternative vote system.

It is affirmed by Henry Tony's opinion: “Artistic means through government to make changes inside state social system, ${ }^{\prime 17}$, which cohabitation polices based on are constitutional rules and items. The result will be as Gabriel Almond said that cohabitation politics are a result of organized process of inputs and outputs interactions to express the performance and abilities of political system throughout taken policies and decisions. Cohabitation policies based on constitutional rules according to the nature of political system are built on government action and on the authority of the legal system which in turn depended on legal commitment. Here, political action appears and is reflected on active real response characterized by generalism, practical response,

\footnotetext{
14 Androo, Renoldez. (2003). Elections and democracy (p. 53). Translated by A. Ayop.

15 Pohoosh, Amar. (2007). Research in political and administrate (p. 12). Alger Publishing.

16 Mihana, Mohamed. (2000). The comparative politics (pp. 100-101). Cairo: Aljameea Publishing.

17 Al-Fahdawy Fahad. (2001). The public policy (p. 60). Al-Masara Publishing.
} 
and future suitability for policies that form a legal base in order to achieve rights. Especially that cohabitation policies' role is to settle internal struggles as Shatsneider says: "The embarrassing problem in policies is represented in struggle management" ${ }^{\prime 18}$, each regime faces embarrassing and intense situations, occupying the minds of policy makers as they reckon into machineries to solve them such as: inquiry, recommendation, description, designation, application, assessment, interpretation, and affirmation ${ }^{19}$.

The making of cohabitation policies needs experts' role to express their ideas and administration role in making polices that are affected by political considerations, and the role of local organs in making administrative decisions. The result will be decisions and policies depend on limited options, super ambitions, preparative behavior, and utilitarian and security concepts that will shape the cohabitation policies.

\section{Chapter Three: Forming Cohabitation Policies for Political Regimes}

\section{Forming Parliamentary System and Policies}

The general policies are suitable for available variation in the authorities of the legislative and executive powers and the prevailing means to comply with the institutional work. Especially that the parliamentary system is based on unique machineries containing procedural democracy and organizational in its institutional and organizational work.

Gabriel Almond expresses the nature of general policies as representing ordered practical result of interactions (demands + support) without puts (capabilities + decisions + policies) to express the political system performance, and its extractive, organizational, distributive, symbolic, responsive, and international capabilities through taken decisions and policies ${ }^{20}$.

The general policies are formal government action learning on constant and developing activities which performed policies toward a particular problem.

Thus, general policies are government action, choices, and institutional takes, and system functioning within organizational interactive frame to join the government dimensions, relations, and behaviors which are called general policies.

Parliamentary system perspective of general policies is determined as macro as an object of huge institutional and public interest that touches all classes and sectors inside society and treats controversial and interesting issues among citizens and parties ${ }^{21}$. This will make it liable to complication and participation by parties, members of parliament, government administrations, mass media, and interest groups, and make it total general policy touching all sectors and tackling general problems. Some total general policy traits in the parliamentary system are $^{22}$ :

(1) Multilateral formal authorities that discuss it;

(2) Interference of the president as participation in spite of his irresponsible role in the parliamentary system;

(3) Making balance and agreement to cover the desires of the widest segment in society.

\footnotetext{
${ }^{18}$ Lindenberg, M., \& Crosby, B. (1981). Managing development: The political dimension (p. 25). New Jersey: Kumarian Press.

${ }^{19}$ Carl J. Friedrich. (1984). Public policy \& the nature of administrative responsibility. In Francis E. Rourke (Ed.), Bureaucracy power in national politics (3rd ed., p. 318). Boston and Toronto: Little, Brown and Company.

${ }_{20}$ Al-Adly, Nasser. (1995). The political behavior-Administration department (p. 485). Jada.

${ }^{21}$ Robert K. Carr, Marver H. Bernstein, \& Walter F. Murphy. (1957). American democracy in theory and practice (p. 195). New York.

${ }^{22}$ Helal, Ali. (2000). The political system issues (p. 132). Beirut.
} 
The formation of general policies in parliamentary system needs a focus on issuing, suffice general and directing states institutions and its administrative organs to undertake and develop responsibilities relying on executive authority suggestions, parliamentary suggestions, and recommendations to execute legislative rules and guaranteeing its activation.

\section{Presidential System Policies}

Presidential system policies are controlled by routine in a special different manner because of the nature of presidential system, type of powers, and attraction, tension, and compromising factors. General policies as Mark Linden Berk defined it: "It is an organizational process characterized by dynamic moving trails of alternation, compromise, and expressing of who gets what? When? And how? As you express what do I want? Who owns it? How can I gain it”,23.

General policies in the presidential system reflect conduct of government and its decisions issued through its institutions that embody political frames, and developing phased plans and programs. Are also interpreted legislations and customs issued by parliament ${ }^{24}$ ? Here the general policies reflect the directions of important authorities which work hard to achieve balance between legislative considerations by legislators and political-executive considerations of the presidential system relying on general interests for the regime and society.

The government in the presidential system stands on customs in delineating general policies. On the one hand, it tries to meet the general needs as such it can without renouncing its interests that can lead the policies toward special trends. On the other hand, the government tries to respond in a procedural and artistic level in the nature of its course subduing its administrative organs to rational coordinative manners in the institutional action, making balance between activity and efficiency in job performance without denouncing the real desire of constructing presidential system glories ${ }^{25}$.

Accordingly, the presidential general policies are without sacrificing the imbibitions of superseding. As a result, the bunch of directed general policies adopted by presidential system help it to supersede and achieve interests of the executive authority particularity in the president office.

\section{General Policies of Semi-Presidential System}

John Dewey defines general policies "as the choice of government to do and not to do within a particular course" as it is a process of controlling behavior, organizing bureaucracies, distributing benefits, and others. Carl Frederick defines it as "a bunch of government decisions including all what have to be done or done under the current conditions" ${ }^{26}$.

Semi-presidential system stands up on analyzing general policies such as characteristics, hardships, relations, programs, traces, demands, and results to delineate and objective policies; this system will make harmonies of the executive and legislative machineries.

Semi-presidential system policies are characterized by rationality, the ability to solve problems, and reaching to planned aims by using reason, evidence, and choosing the suitable policies such as convincing means, attraction, pressure, and compromise which is considered as a negotiating means bear a real desire to

\footnotetext{
${ }^{23}$ Al Jamal, Yehea. The modern political system (p. 176). Cairo: Al Nahda Publishing.

24 Othman, O. (1956). The principles of laws (p. 319). Cairo: Al Maleen Publishing.

25 Mihana, Mohamed. (2000). The comparative politics (pp. 100-101). Cairo: Aljameea Publishing.

26 Al-Heloo, Maged. (1995). The laws (p. 318). Cairo: Aliskandarea Publishing.
} 
achieve an objective, sometimes it stands on exchanging: taking and giving relying on consensual agreements which are active compromising tactics to construct and delineate general policies for a semi-presidential system $^{27}$.

\section{General Policies of Chancellery Cohabitation Governments}

The process of making general policies in the chancellery system depend on complicated ramified dynamic machineries resulting in decisions that direct government course and its various organs. It stands on the unsatisfied needs based on societal loyalty activated by studying the nature of demand and its essence (the problem) wanted to be solved.

In spite of various problems in delineating general policies, the process of categorizing it is part of delineating general policies such as alternative, personal, positive, dynamic, general, distributive, extractive, internal, external, general, private, organizational, procedural, etc. ${ }^{28}$.

Solutions can be civilized policy or welfare, general liberty, or protecting environment policies, etc. Here the role state and its administrative organs are revealed as well as the manner of institutional interactions and the role of unofficial actors in delineating programmed general policies need ${ }^{29}$ :

Legal commitments, public loyalty, legitimacy, power of government and legal commitment, an ability to transcend the possibility of arbitrary decisions and real societal response. The above policies are available in societies that inclined to chancellery system because they are considered as settled societies socially and politically.

In return, James Anderson focuses on essential values in delineating general polices, they are: political values, organizational values, general policies values, individual values, and situational values. The situational manner that general policies makers and organs have to deal with is determined by ${ }^{30}$ :

(1) Leadership manner between consulting and tyranny;

(2) Nature of active decisions and the effect of practical and executive performance;

(3) Decision maker's ability to understand the condition and situation, and create suitable decisions and solutions. This ability of creating solutions and decisions is subjected to many pressures and effective factors such as: compromise in a negotiating process using give and take manner.

There are two types of compromise, one of which is compromising the whole issue, the other is compromising consensual agreement by relying on (something is better than nothing).

(1) Competition in a racing method;

(2) Struggle of two powers each tries to direct decision and policies into its own interests;

(3) Making alliances and agreements;

(4) Cooperation and admissions;

(5) Convincing is a moral rational conscious method ${ }^{31}$.

Thus, general policies include government activates its actions in transforming private individual competitive objectives into general commitments upon which general policies are considered having purposeful quite decisions issued by authorized people through the political system because of their functional position and

27 Al-Bana, Mahmod. (1988). The politics (p. 233). Cairo: Dar Al Fiker.

${ }^{28}$ Helmee, Mahmood. (1935). The history of laws (4th ed., p. 214). Cairo: Dar Al Fiker.

${ }^{29}$ Rbat Admon. (1968). The history of laws (p. 640). Beirut: Dar Alalm.

${ }^{30}$ Metwely, Abid Almamed. Campartive laws and systems in Islam (p. 222). Cairo.

31 Dayton David McKean. (1964). Party and pressure politics (p. 29). New York: Houghton Mifflin Company. 
their responsibilities ${ }^{32}$.

What serve general policies in the chancellery system is constitution which is a body of basic principle according to which a nation or state or political system can be formed and can control. It also refers to a group of agreed rules describing the organization of a particular state's government and they are basic rules that control method of making a decision and assign roles of making policy and divide it regionally, functionally, and the like. The constitution puts conditions of political competition as individuals and groups seek to affect polices by working within the frame of those rules ${ }^{33}$.

The existence of a constitution has a huge role in observing government actions and machinery of making general policy harmonizing all given facts to implement general polices that refer to the political system teaches its people values, passions, and directions allowing for them initiating their required roles, political consensus is a tool to fix unanimity aiming at vertical settlement of one segment of society over the other to ensure stability in society and domination of civil harmony coalescence and peace ${ }^{34}$.

\section{Conclusions}

"Let your courage in the suitable place, and you will not lose" (Macbeth, Shakespeare).

The nature of any political system depends on the degree of distributing authorities, delegations, and specialist Lions that can define the shape of the political system, consequently, the nature of machineries and policies that follow the shape of the political system, especially that the nature of general policies of each system is a group of ideas, practices, and procedures adopted by political system.

Cohabitation policies rely on demands, decisions, contents, outputs, and reflective effect determined by the size of societal satisfaction. The active construction of institutional political action machineries according to methods and convictions has emerged from resultants of economic, social, and political interactions relying on executive bureaucratic roles fed by constitutional items made by legislators' efforts.

Consequently, cohabitation policies are constructed on societal resultants and can be transformed into cohabitation tools and policies which will be reflected to society as there is a quote says "Policies mostly amended rarely altered".

The process of making polices and domesticating demands is all stereotyped by societal satisfaction. The study concludes the following:

(1) Cohabitation policies are made upon power and influence elements whether executive and legislative authorities are in control of political pivots;

(2) Authority is considered as legislative, executive, judicial, procedural, and administrative levels;

(3) The legitimacy of political laws in procedural and administrative levels is determined by the type of constitutional machineries with which it deals;

(4) Cohabitation policies are reflected on ordered process of interactions and outputs, reflecting political system performance and its ability to build successful policies;

(5) The contributions of administrative organs are obvious at the executive policy level;

(6) Legislative policies depend on the role administrators and experts in creating cohabitation legislations and laws;

\footnotetext{
32 Stewart, M. (1962). The modern policy (p. 174). Translated by A. Kameel. Cairo: Dar Alfker.

33 Al-Gasawna, Mostafa. (2009). Parliamentary elections (p. 3). PhD thesis. Aman University.

34 Sherwan, Hasna. (2009). The parliament system (p. 150). The Political Science College Publisher, Sakra University.
} 
(7) Cohabitation policies make machineries and procedures upon which it distinguishes between decisions and policies which would make the direction toward the target adequate;

(8) The progression of cohabitation policies in making legislations orders, systems, and behaviors.

\section{References}

Al-Heloo, M. (1995). The laws (p. 318). Cairo: Aliskandarea Publishing.

Al-Mashehadany, M. (1991). The political system (pp. 53-54). The College of Law, University of Mosul.

Badwee, A. (2004). The political ideas (2nd ed., pp. 64-115). Cairo: Amasree Publishing.

Bordoo, G. (2002). State (3rd ed., pp. 43-53). (S. Hadad, Trans.). Almmen Publishing.

Deab, W. (2013). Islam is forgiveness (p. 12). Bahrain College.

Friedrich, C. J. (1984). Public policy and the nature of administrative responsibility. In Francis E. Rourke (Ed.), Bureaucracy power in national politics (3rd ed., p. 318). Boston and Toronto: Little, Brown and Company.

Hassan, S. (1977). The political science (p. 21). Beirut: Almacen Publisher.

Lindenberg, M., \& Crosby, B. (1981). Managing development: The political dimension (p. 25). New Jersey: Kumarian Press.

McKean, D. D. (1964). Party and pressure politics (p. 29). New York: Houghton Mifflin Company.

Mihana, M. (2000). The comparative politics (pp. 100-101). Cairo: Aljameea Publishing.

Othman, O. (1956). The principles of laws (p. 319). Cairo: Al Maleen Publishing. 